Arja Rosenholm \& Irina Savkina

\title{
Suleika avaa silmänsä - ajatuksia Guzel Jahinan romaanista ja sen "puhdistavasta" ideasta
}

Guzel Jahinan esikoiskirjan Suleika avaa silmänsä (2015, suom. 2016) saamat arvostelut Venäjällä muistuttavat Sofi Oksasen vastaanottoa: aloitteleva, suurelle yleisölle tuntematon - tässä tapauksessa venäjäksi kirjoittava tataaritaustainen kirjailija - julkaisee naisen elämästä romaanin, joka kertoo Neuvostoliiton synkänraskaista historian tapahtumista ja traumaattisista kokemuksista, minkä jälkeen hän herää yllättäen kuuluisana ja voittaa useita arvostettuja kirjallisuuspalkintoja.

Vuonna 2015, heti esikoisromaanin ilmestyttyä Guzel Jahina voitti Vuoden kirja -palkinnon. Sittemmin hän sai myös Jasnaja poljana -palkinnon sekä vuoden merkittävimmän huomionosoituksen, Suuri kirja -palkinnon, joka toi voittajalle kolme miljoonaa ruplaa. ${ }^{1}$ Näiden lisäksi Jahinan romaani nousi Venäläinen Booker -palkinnon finalistilistalle ja Uusi venäläinen kirjallisuus (NOS) -palkintolistalle.

Kiinnostavaa näissä suosionosoituksissa on se, että mainitut palkinnot ja niiden taustavoimat ovat hyvin erilaisia: kun Jasnaja poljana tukee erityisesti kirjallisen perinteen jatkajia, niin liikemies, Mihail Prohorovin perustaman säätiön Uusi venäläinen kirjallisuus -palkinto taas kannustaa ja tukee venäjänkielisen nykykirjallisuuden "uusia trendejä". ${ }^{2}$ Huomionarvoista on myös, että Jahinan tapauksessa Suuri kirja-palkinnon asiantuntijaraadin ja suuren yleisön Facebook-sivuilla antamat äänet ja mielipiteet finalistivalinnasta osuivat yhteen. Romaanin käännösoikeudet on myyty kuuteentoista maahan. Jahinan romaani näyttää siis kiinnostavan kaikkia, niin kriitikoita kuin lukijoita, konservatiiveja ja uudistajia. Kirjan suosiota tuskin selittää vain sen aihevalinta - kulakkien (varakkaiden talonpoikien) pakkosiirron ja vankileirielämän kuvaus. Syitä voi pikemminkin etsiä aiheen moniulotteisesta käsittelystä, mikä selittäisi myös lukijoiden laajan kiinnostuksen. Romaani on samanaikaisesti sekä suopea että vastakarvainen moneen suuntaan. Se liikkuu sekä myyttien ja uskontojen että realistisen todellisuuden rajoilla, esittelee kipeät historian tapahtumat nykylukijalle tutussa populaarikirjallisuuden muodossa, jossa vakava ja kevyt liukenevat toisiinsa ja kauhua huojentaa toive onnesta.

Jahina syntyi vuonna 1977 Kazanissa ja valmistui Kazanin pedagogisen yliopiston vieraiden kielten tiedekunnasta. Vuodesta 1999 lähtien hän on asunut Moskovassa, missä hän on työskennellyt PR- ja mainostoimistoissa. Sittemmin hän on valmistunut myös Moskovan elokuvakoulun käsikirjoitusosastolta. Hän on julkaissut kirjallisuus- 
lehdissä jonkin verran kaunokirjallisuutta, pääosin kertomuksia. Suleika avaa silmänsä on Jahinan ensimmäinen romaani, jonka hän yritti ensin julkaista omakustanteisena, kunnes löysi kustantajan.

Romaani lähtee liikkeelle kuvauksella nuoren talonpoikaisnaisen, Suleikan elämästä tataarikylässä, jossa nöyrä vaimo elää miehensä ja tämän äidin armopaloista. Elämä on raskasta, Suleika on menettänyt ja haudannut neljä tytärtään. Eletään 1930-luvun alkua Neuvostoliitossa, maatalouden kollektivisoinnin ja pakkolunastusten aikaa, kulakkien pakkosiirto on alkanut. Bolševikit murhaavat Suleikan aviomiehen ja Suleika karkotetaan kodistaan. Alkaa pitkällinen kärsimysten matka Siperiaan yhdessä muiden karjavaunuun ahdettujen "kansanvihollisten" kanssa. Haaksirikkoutuneelta proomulta Suleika pelastuu sattumanvaraisesti yhteen kerättyjen pakkosiirrettyjen kanssa. Nämä "kansanviholliset" leiriytyvät Angara-joen rannalle, jonne näistä erilaisista ihmisistä rakentuu vuosien myötä Semrukin kyläyhteisö. Matkan alussa Suleika tietää olevansa raskaana ja synnyttää pojan, joka kasvaa leirillä. Leiriyhteisössä Suleika työskentelee läkärin apuna. Hänestä tulee myös taitava metsästäjä. Suleika kasvaa ja "avaa silmänsä” uusille asioille: ylitetään vanhan ja uuden elämän raja-aitoja, niin myös rakkaudessa, jonka Suleika kokee leirillä. Hän rakastuu tataarimiehensä murhaajaan, leirin johtajaan Ignatoviin, sosialismin periaatteille omistautuneeseen puna-armeijalaiseen. Romaani päättyy sodanjälkeisiin vuosiin: pakkosiirrosta on tullut arkea, jossa Suleikan elämä on muovautunut omanlaisekseen nälän, puutteen ja nöyryytysten mutta myös sitkeyden ja uskalluksen tuloksena.

Tarina vie lukijaa. Suleikan kohtalo kietoo yhteen neuvosto-Venäjän Suuren utopian ja sen valtaisan mullistusvoiman sekä dystooppisen todellisuuden, joka toteutui sekä venäläisten "kansanvihollisten" että kansallisten vähemmistöjen pakkosiirtoina ja työ- ja vankileirien saaristoina. Samalla huomiota sitoo teoksen laji, tai pikemminkin sen hybridinen luonne. Romaanista löytyy kaikkea, mitä lukevan sielu halajaa: viittaukset sosialistisen realismin romaaniin ja sen kulttuurisen muistin välittämään kollektivisointiteemaan, kuten Mihail Šolohovin Aron raivaajiin, sekoittuvat nykyajan mytologisointiin. Etnografinen eksotiikka, kuten tataariperheen arjen kuvaus ja työleirin pystyttäminen Siperian erämaahan, muistuttavat lännen valistusperinteen robinsonadeja ja nykykulttuurin road movie -kuvausta. Lukukokemusta ohjaa tapahtumien vahva visuaalisuus. Elokuvallinen tai sarjamainen poetiikka on selvästi tunnistettavissa kompositiossa ja teoksen kielessä. Sarjallisuuden lisäksi ovat läsnä ja tunnistettavissa muut piirteet, jotka luonnehtivat erityisesti nykypopulaarikulttuuria ja sen vallitsevia (erityisesti melodraaman) esitysmuotoja. Kauhun, jännityksen, rakkauden ja sovituksen vuoropuhelu koukuttaa erilaisia lukijoita, laajentaa lukijapiiriä ja puhuttelee erityisesti niitä, jotka eivät halua keskittyä Gulag-leirien kauheuksiin vaan seuraavat naispäähenkilön kohtaloa. 
Tähän viittaisi eräskin lukija-arvostelu, jossa Suleikaa verrataan Margaret Mitchellin Tuulen viemää -romaanin päähenkilöön, Scarlett O’Haraan. ${ }^{3}$ Ensikatsomalla vertaus itsenäisen ja yritteliään Scarlettin ja nöyrän ja unohdetun tataaritalonpoikaisnaisen välillä tuntuu oudolta. Naisten kertomuksissa voi kuitenkin tunnistaa yhteisiä piirteitä: molemmissa on kyse selviytymisestä ja historian myrskyihin heitettyjen ja heikoiksi uskottujen sitkeydestä. Jahinan Suleika on romaanin alussa nimetön ja äänetön olento. Aviomies puhuttelee häntä "naiseksi”, valtaapitävä ja julma anoppi kutsuu miniäänsä "märäksi kanaksi”‘ sillä seurauksella, että "Suleika [--] alkoi [--] nimittää itseään samoin" (Suleika avaa silmänsä, 9; tästä eteenpäin S). Suleikan historiaa ja kasvamista ei voi tulkita vain sosialistisen aatekaanonin hengessä: tarina ei ole luettavissa "itämaisen naisen vapautumisena", kuten se ei avaudu yksiselitteisen feministisenä "valistuneen naisen" kehityskertomuksena. Romaania voi lukea myös absurdina satuversiona "nukkuvan kaunottaren" heräämisestä: "elävän ruumiin" heräämisestä. Suleika "herää", vaikkakin tuskien ja kärsimysten kautta, tulee naiseksi, joka oppii haluamaan ja toivomaan. Hänestä tulee taitava metsästäjä, joka kykenee puolustamaan itseään ja rakastaan, joka on venäläinen, kommunisti, ateisti - ja hänen aviomiehensä murhaaja. Kuitenkin tärkein asia, joka pakottaa ja motivoi Suleikan "avaamaan silmänsä", heräämään ja syntymään uudelleen, on pyyteetön äidinrakkaus ja äidillinen itsensä uhraaminen. Nälkäinen äiti ruokkii vastasyntynyttä poikaansa, ei vain maidollaan vaan ruumiillaan - sormensa verellä. Hän raataa yöt ja päivät, sietää koettelemukset vain lapsensa Jusufin tähden. Poikansa tähden Suleika lopettaa suhteensa rakastettuunsa, mutta hän myös kasvaa suhteessa lapseensa, josta lopulta päästää irti ja katkaisee vampyyrimäisen ${ }^{5}$ äidin ja pojan välisen suhteen ketjun. Äitiys on tiukasti kytköksissä vastuunkantoon, uskontoon ja perinteeseen, joka leimaa hänen naisen kehoaan ja ohjaa halun kohteita. Perinteen henki ilmestyy tuomitsevan anopin hahmossa aina, kun Suleika päättää ylittää rajoja elämässään ja varoittaa liian uskaliaista päätöksistä. Hybridisten identiteettien kamppailussa nousee esille naisten sukupolvihistorian monitulkintaisuus. Sen ulottuvuuksia Suleika oppii ajan mittaan ymmärtämään vallankäytön ja selviytymisen vyyhtinä.

Jos Suleika on moninainen sekä perinteeseen sitoutuessaan että sitä samalla haastaen, myös tarinan muut henkilöhahmot ovat vastakarvaisia, lukuun ottamatta patologisia roistoja, kuten leiririkollista ja opportunistia Gorelovia sekä salaisen poliisin NKVD:n edustajaa, Zinovi Kuznetsia. Jahina liottaa ideologisia blokkeja ja henkilöhahmot vastustavat yksiselitteisyyttä moneen suuntaan: tataariperheen sukupuolijärjestys on alistava, samalla usko on Suleikalle voimanlähde. Ateistinen leirijohtaja Ignatov puolestaan ei ole vain paha vaan muuttuu kulakkien pyövelistä leiriläisten pelastajaksi. Romaanin historia ja sen nykytulkinta haastavat Venäjällä vahvistuneen valtiopatriotismin ja eri uskontojen nationalistiset tulkinnat. Vastustaessaan yksiselitteisyyttä romaani on luettavissa hyvinkin eri näkökulmista, mikä myös selittää erilaisten lukijoiden suosion. Samaisesta syystä romaani on ollut myös kritiikin kohde. Tatarstanissa reagoitiin 
romaaniin myös kriittisesti: kirjailijaa kritisoitiin kansallisen menneisyyden halventamisesta ja perinteistä luopumisesta. Vaikka kirjailija ei idealisoikaan perinteitä, hän ei niiden arvoja myöskään kiellä.

Romaani purkaa kansallisia perinteitä ja uskonnollisia dogmeja. Se nostaa esille, mikä eri uskonnoille on yhteistä; että Jumala ei ole ihmisten yläpuolella vaan heidän keskuudessaan. Tästä kertoo romaanissa kaksi tärkeää symbolista kohtausta. Ensimmäinen viittaa kristilliseen kontekstiin. Leningradilainen taiteilija, Ikonnikov, joka on yksi pakkosiirretyistä, saa tehtäväkseen sisustaa leirin kerhotilan, ja "vallankumouksellisen agitaation" nimissä hän piirtää kattoon kuvia, jotka muistuttavat kirkon kupolien ikoneita. Sotilas, läkäri, agronomi ja äiti lapsensa kera, kaikki romaanin hahmoja, kuvataan katon neljässä nurkkauksessa paikalla, jossa kristillisessä kirkossa tavallisesti kuvataan enkeleitä tai evankelistoja: "He ovat [--] rohkeita ja erittäin keskittyneitä, heillä on vain yksi pyrkimys - ulottua päämäärään. Mihin? Katon keskellä on tyhjää. - He pyrkivät siihen, mitä ei ole, niinkö?”, kysyy taiteilijalta toinen karkotettu, Isabella. ”Ei, Bella, [--] he pyrkivät toistensa luo", vastaa Ikonnikov. (S, 380.)

Sen jälkeen Ikonnikov viimeistelee neuvostojohtajien häneltä tilaaman työn. Katon keskellä olevaan tyhjään tilaan hän maalaa verenpunaisen lipun, joka ei näytä olevan symbolisten henkilöhahmojen kurkotuksen kohde tai päämärä vaan pikemminkin este heidän yhteisöllisyydelleen.

Toinen vastaava symbolinen episodi liittyy itämaisen legendan šaahi-lintuun, Semrugiin, josta Suleika kertoo pojalleen Jusufille muistuttaen tätä tataarikulttuurin kansanperinteestä. Legenda kertoo, miten kaikki maan linnut riitautuivat ja lähtivät etsimään šaahi-lintua, korkeinta voimaa, joka lopettaisi riitaisuudet. Ne kulkevat halki laaksojen ja päätyvät lopulta iäisyyden Maahan, jumalaisen Semrug-linnun palatsiin. "Heidän silmänsä sulkeutuivat maailman täyttäneen kirkkauden edessä, ja kun ne aukesivat, he näkivät vain toisensa. Sillä hetkellä he käsittivät tärkeimmän: he kaikki ovatkin Semrug. Sekä kukin erikseen että kaikki yhdessä.” (S, 363.)

Saman jumalallisen ajatuksen bolševikki-Ignatov uskoo kaikuvan myös neuvostohaaveen yhdistämässä veljeydessä ja tasa-arvossa, sosialistisessa paratiisissa, joka ilmaisee itseään ihmisten yhteisöllisyydessä heidän kurkottaessaan toistensa luo. Suuren utopian toteuttaminen kääntyy kuitenkin kammottavaksi dystopiaksi: maanpäällisen paratiisin sijasta Siperian erämaahan synnytetään kyläpahanen, neuvosto-Semruk - eristetty alue, jota leimaa loputon työ ja nöyryyttäminen. Romaani kietoo toisiinsa uskon ja epäuskon, luo eri ideologioiden välille yhteyksiä ja häivyttää niiden rajoja. Tärkeää on, että elämä, johon ihmiset on heitetty, on arvokasta - kaikesta huolimatta.

Jahinan historiallisen romaanin teema ei ole uusi. Lukija tunnistaa tuttuja juonipolkuja ja henkilöhahmoja sekä venäläistä kulttuuria leimaavan utopian ja dystopian vuoropuhelun. Uutta etsivää lukijaa voi puolestaan motivoida nuoren sukupolven kirjailijan näkemys Neuvostoliiton traagisista historian tapahtumista. Vuonna 1977 syn- 
tyneenä Jahina kuuluu viimeiseen sukupolveen, joka on kuullut tapahtumista henkilökohtaisesti. Jahina onkin sanonut muistelevansa isoäitinsä kertomuksia, joita oli kuullut lapsena. Tekijä on kuitenkin jo kommunikatiivisen ja kulttuurisen muistin rajalla, sillä kulttuurisen muistin representaatiot, kuten historiankirjoitus, kirjallisuus ja elokuvat, työntävät tieltään omaelämäkerrallisen muistin välitöntä kokemushistoriaa. Romaanin monikerroksisen muistivarannon avulla tekijä tulkitsee kipeitä tapahtumia, antaa niille uusia merkityksiä omassa ajassaan ja siten vastustaa kollektiivista muistinmenetystä. Kulttuurisen muistin varantoa hyödyntämällä syntyy siis mahdollisuus muutokseen.

Jahinan romaanin Suleika on matkalla, miltei koko elämänsä. Elämä ja sosialismi ovat koko ajan tulollaan. Lukijalle syntyy vaikutelma, että ei elämä, sen paremmin kuin sen esittäminenkään voi olla kokonaista, mikään ei kehkeydy valmiiksi asti, mutta menneestä ja ahdistavasta voi päästää irti. Tässä keskeneräisessä voi piillä myös se avoimuuden ulottuvuus, joka kätkee sisälleen tekstin lumovoiman. Romaani muistuttaa moninaisten identiteettien historiasta osana (neuvosto-)Venäjän monikansallisten ja monikulttuuristen kertomusten muistiketjua. Jos Jahinan romaani kysyy Suleikalta, mihin ja keiden historiaan tämä kuuluu, vastaus ei voi olla yksiselitteinen.

Esseemme alun vertaus Jahinan ja Sofi Oksasen vastaanotosta ja heidän rooleistaan yhteiskunnallisina vaikuttajina herättää useita kysymyksiä. Kun kirjailija Sofi Oksanen on näkyvä suomalaisen kulttuurielämän vaikuttaja, Guzel Jahina on venäläiselle medialle melko tuntematon. Huolimatta useista kirjallisista palkinnoista häntä ei näy venäläisen valtamedian - etenkään television - talk show -ohjelmissa. Ristiriita motivoi miettimään kirjallisuuden ja valtamedioiden välisiä suhteita. Palkitaanko kriittinen kirjallisuus, kunhan se jää valtamedioiden ulkopuolelle, mistä käsin se voi haastaa virallisen historiankirjoituksen? Onko venäläisen kirjailijan ja kirjallisuuden keskeinen rooli muuttunut ja kaunokirjallisuus menettämässä merkitystään yhteiskunnallisena vaikuttajadiskurssina?

\section{Viitteet}

${ }^{1}$ Suuri kirja -palkinnon virallinen sivu: http://www.bigbook.ru/

${ }^{2}$ NOS (Novaja slovesnost), virallinen sivu: http://www.prokhorovfund.ru/projects/own/108/

${ }^{3}$ bookeanarium: Sibirskaja Skarlett, ili Zuleiha otkryvajet glaza. https://www.livelib.ru/ review/571264

${ }^{4}$ suomennoksessa "rääpäle"

${ }^{5}$ Suleika kutsuu mielessään miehensä äitiä nimellä Upyriha (suomennoksessa Käärmenoita), joka on feminiininen muoto slaavilaisesta kansanperinteen sanasta upyr', s.o. "verenimijä", "vampyyri".

\section{Kirjallisuus}

Jahina, Guzel 2016. Suleika avaa silmänsä. (Zuleiha otkryvajet glaza, 2015.) Suom. Kirsti Era. Helsinki: Into. 